\title{
Produksi Biogas dari Limbah Black Water dan Kotoran Ternak Menggunakan Reaktor Upflow Anaerobic Sludge Blanket (UASB)
}

\author{
Biogas Production from Black Water and Cattle Manure in Upflow Anaerobic \\ Sludge Blanket (UASB) Reactor
}

\author{
P. K. Wardhani' ${ }^{1}$, S. Amizera ${ }^{2}$ dan F. H. Prima ${ }^{3}$ \\ ${ }^{1}$ Jurusan Teknik Sipil dan Perencanaan, Fakultas Teknik, Universitas Sriwijaya \\ ${ }^{2}$ Prodi Pengelolaan Lingkungan, Program Magister Pascasarjana Universitas Sriwijaya \\ 3Program Studi Teknik Pertanian, Fakultas Pertanian, Universitas Sriwijaya \\ ${ }^{1}$ Corresponding e-mail : puterikusumawardhani@unsri.ac.id
}

\begin{abstract}
This research investigated the biogas production and removal efficiency of BOD, COD, TSS, and pathogen (E.coli) from black water and cattle manure using a Upflow Anaerobic Sludge Blanket (UASB) reactor in mesophilic condition $\left(28-30{ }^{\circ} \mathrm{C}\right)$. The results shows the removal efficiency of COD, TSS, and BOD was $67,8 \%$, $92,5 \%$, and 36,9 \%, respectively. Biogas production was measured on day 6 , day 14, and day 21, consisted of 21 $\%, 51 \%$, and $64 \%$ of methane, and $21 \%, 34 \%$, and $33 \%$ of carbon dioxide, respectively. These can be concluded that the treatment of black water and cattle manure can be obtained under anaerobic condition using UASB reactor. In addition, the anaerobic process of black water and cattle manure exhibit substantial advantage due to methane generation.
\end{abstract}

Keywords: biogas, black water, UASB reactor

\begin{abstract}
ABSTRAK
Penelitian ini bertujuan untuk menginvestigasi produksi biogas serta efisiensi penyisihan BOD, COD, TSS, dan keberadaan organisme patogen (E. coli) dari limbah black water dan kotoran ternak menggunakan reaktor Upflow Anaerobic Sludge Blanket (UASB) pada temperatur mesofilik $\left(28-30^{\circ} \mathrm{C}\right)$. Hasil penelitian menunjukkan bahwa efisiensi penyisihan COD, TSS, dan BOD sebesar 67,8 \%, 92, $5 \%$, dan 36, $9 \%$. Biogas yang dihasilkan pada hari ke 7, hari ke 14 dan hari ke 21 meliputi $12 \%, 51 \%$, dan $64 \%$ untuk metan, sementara karbon dioksida sebesar $21 \%, 34 \%$, dan $33 \%$. Hal ini menunjukkan bahwa pengolahan limbah black water dan kotoran ternak secara anaerobik dapat diterapkan dengan menggunakan reaktor UASB. Selain itu, pengolahan limbah black water dan kotoran ternak secara anaerobik dengan reaktor UASB memberikan manfaat yang besar dalam menghasilkan metan.
\end{abstract}

Kata kunci: biogas, black water, reaktor UASB

\section{PENDAHULUAN}

Energi merupakan aspek penting yang mendukung hampir semua aktivitas manusia. Beberapa sektor kegiatan manusia pada umumnya masih menggunakan energi yang berasal dari fosil, meliputi minyak bumi dan gas bumi. Penggunaan bahan bakar fosil yang tinggi akan memberikan dampak negatif terhadap lingkungan. Pembakaran yang tidak sempurna pada bahan bakar fosil dapat meningkatkan jumlah gas $\mathrm{CO}_{2}$ yang menyebabkan konsentrasi gas rumah kaca di atmosfer meningkat. (Ilyas, 2015).

Pengembangan energi baru dan terbarukan yang ramah lingkungan merupakan alternatif dalam mengatasi isu lingkungan terkait energi. Energi alternatif yang bisa diterapkan yakni dengan menggunakan bahan organik menjadi biogas (Ilyas, 2015). Biogas merupakan gas yang dihasilkan dari proses anaerobik (tanpa oksigen) dari material organik seperti blackwater, kotoran ternak, sampah organik, dan material organik lainnya dengan bantuan mikroorganisme anaerob (Demirbas et al., 2016).

Proses anaerobik terjadi dua tahapan yakni fase hidrolisis dan fase pembentukan metana (methanogenesis). Pada fase hidrolisis, bakteri anaerobik dan bakteri fakultatif mengurai senyawa organik komplek menjadi molekul yang lebih sederhana, sehingga senyawa komplek akan terbentuk menjadi senyawa asam organik (seperti asam setat). Pada fase methanogenesis, bakteri 
penghasil metan akan mengurai senyawa yang dihasilkan pada fase sebelumnya menjadi karbon dioksida $\left(\mathrm{CO}_{2}\right)$ dan metan $\left(\mathrm{CH}_{4}\right)$ (J. Mata-Alvarez, 2000).

Biogas menjadi salah satu alternatif energi pengganti bahan bakar fosil dengan komposisi gas terdiri atas metana $(55-75 \%)$, karbon dioksida (25 - 45\%), sisanya terdiri atas nitrogen, hidrogen dan hidrogen sulfida dalam jumlah kecil (Demirbas et al., 2016). Metana menjadi komponen penting dalam biogas yang digunakan sebagai pengganti bahan bakar untuk kendaraan, kompor, dan listrik.

Pemanfaatan bahan organik seperti limbah black water dalam menghasilkan biogas telah dilakukan oleh beberapa peneliti. Hasil studi melaporkan adanya penyisihan COD yang tinggi (61 - 80\%) dan produksi metana yang tinggi (39 $60 \%$ ). Perbedaan nilai penyisihan COD dan metana yang dihasilkan bisa terjadi karena beberapa faktor meliputi sistem bioreaktor yang digunakan (CSTR-continuously stirred tank reactor, sistem akumulasi, dan upflow anaerobic sludge blanket - UASB), serta temperatur yang digunakan dalam proses anaerobik (psychro-philic dan mesopihilic) (Gao et al., 2019).

Penggunaan reaktor UASB pada penelitian ini dengan mempertimbangkan beberapa keunggulan seperti biaya pembuatan yang terjangkau, operasional yang rendah, dan memiliki efisiensi yang tinggi dalam mengurangi kandungan organik dalam limbah (Adhikari dan Lohani, 2019). Aplikasi dari teknologi ini telah dilakukan untuk pengolahan limbah cair domestik terpusat di beberapa negara seperti India, Pakistan, Cina, Kolumbia, Brazil, Mesir, dan Indonesia. Kinerja reaktor dipengaruhi oleh beberapa faktor yang meliputi kondisi hidrolik, kapasitas beban pencemar dalam air limbah, dan operasional reaktor. (Haandel dan Lettinga, 1994; Ghangrekar et al, 1996; Nugrahini et al., 2008 dalam Yazid et al., 2012; Lew et al, 2004; Aslan dan Sekerdag, 2008 dalam Yazid et al., 2012; Al-Shayah dan Mahmoud, 2008; Yasar et al, 2007).

Beberapa penelitian yang dilakukan di luar Indonesia masih terbatas pada kajian kinerja reaktor UASB dengan kondisi iklim sub tropis yang terdiri atas empat musim, sementara di Indonesia merupakan negara iklim tropis yang terdiri atas dua musim. Selain itu, penelitian yang sudah dilakukan mengenai kinerja reaktor UASB fokus terhadap parameter COD (Ghangrekar dan Kahalekar, 2003; Yasar et al., 2007; Lew et al.,
2004; Leal et al., 2010; Halalsheh, 2005; Sibel Aslan dan Nusret Sekerdag, 2008; Elmitwalli dan Otterpohl, 2011). Penelitian-penelitian tersebut belum banyak memberikan kajian mengenai produksi biogas serta penyisihan BOD, TSS dan E.coli pada limbah cair domestik di daerah tropis. Berdasarkan penjelasan yang telah dipaparkan, perlu dilakukan kajian lebih lanjut mengenai produksi biogas serta penyisihan BOD, TSS dan E. coli dari limbah black water menggunakan reaktor UASB. Limbah black water dengan rasio $\mathrm{C} / \mathrm{N}$ yang rendah perlu ditambahkan material organik yang tinggi nitrogen agar mencapai nilai $\mathrm{C} / \mathrm{N}$ yang ideal, yakni antara 25 35 (Demirbas et al., 2016). Sehingga, pada penelitian ini digunakan kotoran ternak sebagai sumber material organik yang kaya nitrogen.

\section{MATERI DAN METODE}

Penelitian ini merupakan eksperimentasi kuantitatif yang terdiri atas beberapa tahapan yang meliputi uji awal karakteristik limbah black water dan kotoran sapi, start-up dan aklimatisasi, serta running. Uji karakteristik awal limbah black water dilakukan dengan sampling di TPA Sukawinatan Palembang dengan mengukur nilai COD, BOD, TSS, dan E. coli. Tahap start-up dan aklimatisasi merupakan tahap pengkondisian mikroorganisme agar dapat hidup dan melakukan adaptasi. Pada fase ini, limbah dalam reaktor dijaga agar mencapai steady state yang ditandai dengan nilai selisih efisiensi penurunan COD kurang dari $10 \%$. Kondisi steady state telah didapati maka dilanjutkan pada tahap terakhir yaitu running. Pada tahap running dilakukan penambahan kotoran sapi ke dalam limbah blackwater dengan komposisi limbah dan kotoran sapi sebesar $1: 1$ (1,5 L air limbah dan 1,5 L kotoran ternak).

Reaktor UASB yang digunakan pada penelitian ini adalah Armfield Anaerobic Digester - W8. Reaktor terdiri atas dua buah tangki berukuran 5 liter yang masing-masing dilengkapi kontrol laju alir dan temperatur. Pengaturan temperatur pada masing-masing tangki digester menggunakan electric heating mat disekeliling dinding tangki. Gas yang terbentuk pada proses anaerobik dari reaktor dikumpulkan di dalam tangki gas yang perhitungannya dilakukan menggunakan metode water displacement. Rangkaian reaktor yang digunakan pada penelitian dapat dilihat pada Gambar 1. 


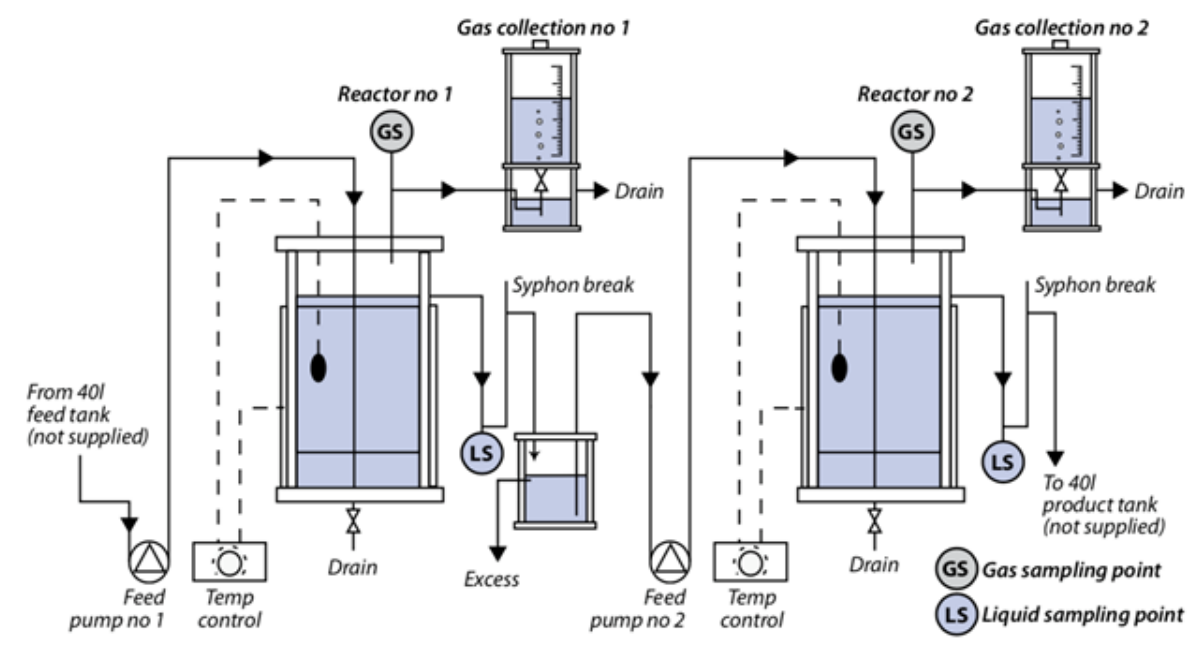

Gambar 1. Ilustrasi Reaktor Armfield Ltd. Anaerobic Digester (W8). (Sumber: http://www.discoverarmfield.co.uk/data/w8/.)

Pengukuran parameter air limbah yang meliputi komposisi biogas (metana dan karbon dioksida), COD, BOD, TSS, dan E.coli dilakukan sesuai dengan standar yang baku. Pengukuran komposisi biogas dilakukan tiga kali selama 21 hari proses anaerobik, yakni pada hari ke 7 , hari ke 14, dan hari ke 21.

\section{HASIL DAN PEMBAHASAN}

\section{Penyisihan BOD, COD, TSS, dan E.coli}

Air limbah blackwater yang digunakan pada penelitian merupakan limbah yang berasal dari lumpur tinja. Temperatur pada reaktor dikondisikan pada keadaan mesophilic dengan rentang temperatur $28-30^{\circ} \mathrm{C}$. Karakteristik air limbah blackwater yang berasal dari TPA Sukawinatan Palembang ditampilkan pada Tabel 1. Lumpur tinja yang dikumpulkan di TPA Sukawinatan dimasukkan ke dalam kolam, dan hanya terjadi proses pengendapan di dalam kolam. Kondisi tersebut menyebabkan kadar organik limbah cukup tinggi karena tidak terjadi proses apapun pada kolam lumpur tinja. Rasio $\mathrm{C} / \mathrm{N}$ pada limbah dikondisikan agar berada pada nilai yang ideal untuk proses anaerobik dengan menambahkan kotoran ternak.

Nilai COD awal air limbah sebesar $540,485 \mathrm{mg} / \mathrm{L}$, mengalami penurunan konsentrasi menjadi $174 \mathrm{mg} / \mathrm{L}$. Hal ini menunjukkan adanya pertumbuhan populasi mikroorganisme anaerobik (Ahmad et al., 2011). Jika dibandingkan dengan penelitian serupa yang dilakukan oleh Khan et al. (2015), efisiensi penurunan COD masih dikategorikan rendah, memiliki rentang penyisihan 65 hingga $85 \%$. Sedangkan penyisihan BOD masih rendah jika dibandingkan dengan penelitian terdahulu, dimana efisiensi penyisihan sebesar $36,9 \%$. Pertumbuhan populasi mikroorganisme dipengaruhi oleh waktu tinggal. Waktu tinggal mikroorganisme yang lama akan mempengaruhi waktu kontak antara mikroorganisme dengan bahan organik pada air limbah, sehingga akan mempengaruhi proses degradasi bahan organik dalam limbah cair (Ahmad et al., 2011). Selain itu, kemungkingan adanya nitrogen dan ammonia dalam konsentrasi tinggi juga menjadi salah satu faktor yang menyebabkan efisiensi penyisihan yang rendah pada beberapa kasus (Nasr \& Mikhaeil, 2014).

Tabel 1. Efisiensi penyisihan BOD, COD, TSS, dan E.coli

\begin{tabular}{lllll}
\hline & Influent & Effluent & Efisiensi (\%) & Satuan \\
\hline COD & 540,485 & 174 & 67,8 & $\mathrm{mg} / \mathrm{L}$ \\
TSS & 306,5 & 22,9 & 92,5 & $\mathrm{mg} / \mathrm{L}$ \\
BOD & 73,4 & 46,3 & 36,9 & $\mathrm{mg} / \mathrm{L}$ \\
\hline E.coli & 16000 & 12000 & 25 & $\mathrm{jml} / 100 \mathrm{~mL}$ \\
\hline C/N & 28,3 & - & - & - \\
\hline
\end{tabular}

Sumber: Hasil analisa, 2020 
Beberapa penelitian melaporkan bahwa ammonia dalam konsentrasi yang tinggi ditemukan pada digester anaerobik yang menggunakan sampel limbah blackwater dan kotoran ternak (Sun et al.., 2014; De Vrieze et al.., 2015; Muller et al., 2016; Tian et al., 2018). Ammonia dapat menghambat pertumbuhan mikroorganisme dan mengurangi efisiensi penyisihan COD dan BOD, serta efisiensi produksi metan (Gao et al.., 2019).

Nilai TSS awal air limbah sebesar 306,5 $\mathrm{mg} / \mathrm{L}$, mengalami penurunan pada akhir proses anaerobik yakni sebesar $22,9 \mathrm{mg} / \mathrm{L}$. Penurunan konsentrasi TSS menandakan adanya pengaruh proses pengolahan secara anaerobik terhadap nilai TSS. Pada proses anaerobik, material kompleks akan diurai oleh bakteri anaerobik dan fakultatif anaerob menjadi material yang lebih sederhana. Proses penguraian ini akan menyebabkan penurunan TSS karena adanya perubahan partikel/ukuran material organik menjadi lebih kecil (proses degradasi) (Doraja et al., 2012).

Penyisihan E.coli dengan reaktor UASB hanya dapat dicapai sebesar $25 \%$. Beberapa riset menunjukkan adanya pengaruh yang signifikan dari jenis septic tank yang digunakan serta hydraulic retention time (HRT) (Nasr \& Mikhaeil, 2014). Kamel \& Hgazy (2006) melaporkan bahwa esifiensi penyisihan E.coli yang tinggi dengan menggunakan sistem septic tank yang dimodifikasi. Kujawa-Roeleveld, et al. (2005) menginvestigasi efisiensi penyisihan $E$. coli pada limbah blackwater dengan suhu $15^{\circ} \mathrm{C}$ dan $25^{\circ} \mathrm{C}$. Suhu yang tinggi dilaporkan memiliki efisiensi penyisihan yang lebih tinggi. Hal ini menunjukkan bahwa perlunya pengolahan lebih lanjut effluent dari proses anaerobik dengan reaktor UASB agar effluent yang dihasilkan sesuai dengan standar baku mutu.

Rasio C/N merupakan salah satu parameter yang perlu diperhatikan dalam proses anaerobik. Rasio $\mathrm{C} / \mathrm{N}$ yang ideal berada pada rentang 16 - 25 (Deublein \& Steinhauser, 2008) atau 25 - 35 (Demirbas et al., 2016). Rasio C/N yang tinggi menandakan rendahnya kandungan nitrogen pada limbah, sementara rasio $\mathrm{C} / \mathrm{N}$ yang rendah dapat menyebabkan peningkatan produksi ammonia yang dapat menghambat produksi gas metan (Deublein \& Steinhauser, 2008). Oleh karena itu, rasio $\mathrm{C} / \mathrm{N}$ perlu dijaga pada nilai yang ideal untuk proses anaerobik.

\section{Produksi Biogas}

Proses degradasi material organik yang terdapat pada limbah black water ditunjukkan dengan penurunan konsentrasi COD. Produksi biogas berbanding terbalik dimana seiring dengan penurunan konsentrasi COD, volume biogas semakin meningkat (Gambar 2). Titik temu antara nilai COD dan produksi biogas terjadi pada hari ke 10 yang merupakan waktu optimal proses degradasi mikroba, sehingga dapat dilakukan proses feeding bahan baku (Hermanto \& Susanty, 2015).

Komposisi biogas pada pengukuran hari ke-7, hari ke-14, dan hari ke-21 dapat dilihat pada Tabel 2. Terjadi peningkatan metan hingga mencapai $64 \%$, sementara karbon dioksida mencapai $33 \%$ dimana nilai tersebut sesuai dengan komposisi biogas yang terdapat pada literatur (Demirbas et al., 2016). Pada 10 hari proses produksi biogas, konsentrasi metan yang dihasilkan masih dalam jumlah yang sedikit. Hal ini disebabkan pada awal proses, komponen organik yang dikonversi menjadi metan belum begitu optimal. Komposisi karbon dioksida yang tinggi dibandingkan metan pada hari ke-6 disebabkan adanya proses oksidasi biologi penyisihan COD (Zamalloa et al., 2013).

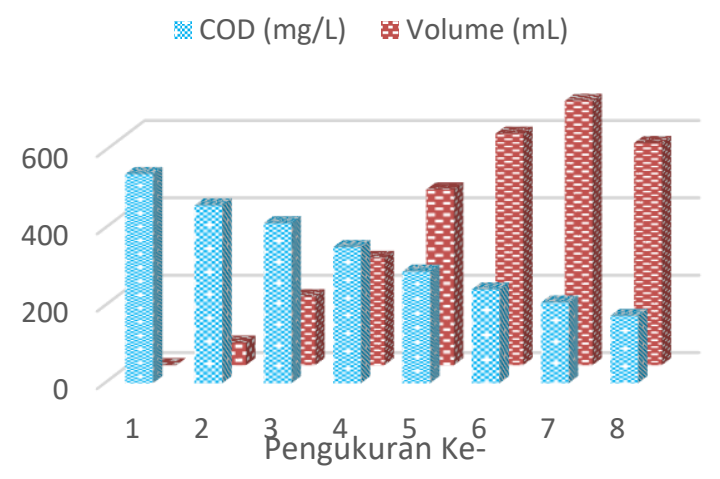

Gambar 2. Grafik Hubungan Produksi Biogas dan Penyisihan COD

Pertumbuhan bakteri metan yang rendah, sekitar 5 hingga 16 hari, juga bisa memberikan kontribusi terhadap rendahnya konsentrasi metan pada 10 hari pertama (Wardhani, 2017). Sehingga, fase start-up dibutuhkan dalam jangka waktu yang lebih lama agar pertumbuhan bakteri metan menjadi optimal. Selain itu, kondisi limbah blackwater yang rentan terjadi peningkatan konsentrasi amonia. Konsentrasi amonia dapat meningkat karena proses deamonifikasi komponen nitrogen organik yang terdapat pada feses dan juga konversi urea dalam urin (Chaggu et al., 2007). Amonia dalam konsentrasi tinggi dapat menghambat proses hidrolisis dan 
methanogenesis (Chaggu et al., 2007; El-Mashad, 2003 dalam Chaggu et al., 2007).

Tabel 2. Komposisi metan $\left(\mathrm{CH}_{4}\right)$ dan karbondioksida $\left(\mathrm{CO}_{2}\right)$

\begin{tabular}{lccc}
\hline \multicolumn{1}{c}{$\begin{array}{c}\text { Komposisi } \\
\text { Biogas }\end{array}$} & $\begin{array}{c}\text { Hari } \\
\text { ke - } 7\end{array}$ & $\begin{array}{c}\text { Hari } \\
\text { ke - 14 }\end{array}$ & $\begin{array}{c}\text { Hari } \\
\text { ke - } 21\end{array}$ \\
\hline $\begin{array}{l}\text { Metan }\left(\mathrm{CH}_{4}\right) \\
12 \%\end{array}$ & $51 \%$ & $64 \%$ \\
$\begin{array}{l}\text { Karbon dioksida } \\
\left(\mathrm{CO}_{2}\right)\end{array}$ & $21 \%$ & $34 \%$ & $33 \%$ \\
\hline
\end{tabular}

Sumber: Hasil analisa, 2020

\section{KESIMPULAN DAN SARAN}

Penelitian ini menunjukkan bahwa pengolahan limbah blackwater dan kotoran ternak secara anaerobik dapat diterapkan dengan menggunakan reaktor UASB. Efisiensi penyisihan COD dan TSS yang tinggi, serta produksi gas metan menjadi hal yang substansial dalam pemenuhan energi baru dan terbarukan yang berkelanjutan. Limbah black water yang terdiri atas feses dan urin mengandung rasio $\mathrm{C} / \mathrm{N}$ yang rendah, sehingga penambahan kotoran ternak dapat memenuhi rasio $\mathrm{C} / \mathrm{N}$ yang ideal dalam proses anaerobik. Namun, perlu diperhatikan keberadaan amonia pada limbah blackwater dan kotoroan ternak, sehingga produksi biogas dan efisiensi penyisihan COD dan BOD dapat ditingkatkan. Selain itu, effluent yang dihasilkan belum memenuhi standar baku mutu sehingga perlu dilakukan post treatment agar tidak menjadi permasalahan bagi lingkungan.

\section{UCAPAN TERIMA KASIH}

Penulis mengucapkan terima kasih kepada Universitas Sriwijaya yang telah memberikan dana penelitian melalui hibah penelitian skema Sains, Teknologi, dan Seni (SATEK) Universitas Sriwijaya dengan kontrak nomor $0684 / \mathrm{UN} 9 / \mathrm{SK}$.BUK.KP/2020 tanggal 15 Juli 2020.

\section{DAFTAR PUSTAKA}

Adhikari, J. R., and S. P. Lohani. 2019. Design, installation, operation and experimentation of septic tank - UASB wastewater treatment system. Renewable Energy. 143; 1406-1415.
Ahmad, A., S. Syarfi, dan M. Atikalidia. 2011. Penyisihan Chemical Oxygen Demand (COD) dan Produksi Biogas Limbah Cair Pabrik Kelapa Sawit Dengan Bioreaktor Hibrid Anaerob Bermedia Cangkang Sawit. In Prosiding Seminar Nasional Teknik Kimia “Kejuangan” 2011 (pp. A03-1). UPN" Veteran" Yogyakarta.

Al-Shayah, M., and N. Mahmoud. 2008. Start-up of an UASB-septic tank for community onsite treatment of strong domestic sewage. Bioresource Technology. 99(16); 77587766.

Chaggu, E. J., W. Sanders, G. Lettinga. 2007. Demonstration of Anaerobic Stabilization of Black Water in Accumulation Systems Under Tropical Conditions. Bioresource Technology. 98(16); 3090 - 3097.

De Vrieze, J., A.M. Saunders, Y. He, J. Fang, P. H. Nielsen, W. Verstraete, and N. Boon. 2015. Ammonia and temperature determine potential clustering in the anaerobic digestion microbiome. Water Research. 75; 312-323.

Deublein, D., and A. Steinhauser. 2008. Biogas from Waste and Renewable Resources. A John Wiley and Sons, Inc., Publication. ISBN 978-3-527-31841-4.

Doraja, P. H., M. Shovitri, dan N. D. Kuswitasari. 2012. Biodegradasi Limbah Domestik dengan Menggunakan Inokulum Alami dari Tangki Septik. Jurnal Sains dan Seni ITS. 1(1); 44 - 47.

Elmitwalli, T., and R. Otterpohl. 2011. Grey water treatment in upflow anaerobic sludge blanket (UASB) reactor at different temperatures. Water Science and Technology. 64(3); 610-617.

Gao, M, B. Guo, L. Zhang, Y. Zhang, and Y. Liu. 2019. Microbial Community Dynamics in Anaerobic Digesters Treating Conventional and Vaccum Toilet Flushed Blackwater. Water Research. 160; 249 - 258.

Ghangrekar, M. M., and U. J. Kahalekar. 2003. Performance and cost efficacy of two- stage anaerobic sewage treatment. Journal of the Institution of Engineers(India), Part EN, Environmental Engineering Division, 84(1), 16-22.

Ghangrekar, M. M., S. R. Asolekar, K. R. Ranganathan, and S. G. Joshi. 1996. 
Experience with UASB reactor start-up under different operating conditions. Water Science and Technology. 34 (5-6-6 pt 3); 421-428.

Halalsheh, M., J. Koppes, J. Den Elzen, G. Zeeman, M. Fayyad, and G. Lettinga, 2005. Effect of SRT and temperature on biological conversions and the related scum-forming potential. Water Research. 39(12); 2475-2482.

Hermanto, dan A. Susanty. 2015. Produksi Biogas dari Limbah Kelapa Sawit Menggunakan Bioreaktor Up-Flow Anaerobik Sludge Blanket (UASB). Jurnal Riset Teknologi Industri. 9(1); 56 - 63.

Ilyas. 2015. Potensi Pemanfaatan Kotoran Sapi menjadi Biogas sebagai Energi Alternatif di Desa Ciporeat Kecamatan Cilengkrang Kabupaten Bandung. Skripsi Departemen Pendidikan Geografi, Universitas Pendidikan Indonesia

J. Mata-Alvarez, S. Mace, and P. Llabres. 2000 . Anaerobic digestion of organic solid wastes. An overview of research achievements and perspectives, Bioresour. Technol. 74, 3 - 16.

Kahalekar, U. 2003. Performance and Cost Efficacy of Two stage Anaerobic Sewage Treatment. Journal of the Institution of Engineers (India): Environmental Engineering Division. 84.

Kamel, M. M. and B. E. Hgazy. 2006. A Septic Tank System: On Site Disposal. J. Appl. Sci. 6(10), 2269 - 2274.

Khan, A.A., I. Mehrotra, and A.A. Kazmi. 2015. Sludge Profiling at Varied Organic Loadings and Performance Evaluation of UASB Reactor Treating Sewage. Biosyst. Eng. 131, 32 - 40.

Kujawa-Roeleveld, K., T. Fernandes, Y. Wiryawan, A. Tawfik, M. Visser, and G. Zeeman. 2005. Performance of UASB Septic Tank for Treatment of Concentrated Black Water within DESAR Concept. Water Science and Technology, 52(1 - 2), $307-313$.

Leal, L. H., H. Temmink, G. Zeeman, and C. J. Cees. 2010. Comparison of three systems for biological greywater treatment. Water (Switzerland), 2(2), 155-169
Lew, B., S. Tarre, M. Belavski, and M. Green. 2004. UASB reactor for domestic wastewater treatment at low temperatures: A comparison between a classical UASB and hybrid UASB-filter reactor. Water Science and Technology, 49(11-12), 295301.

Muller, B., L. Sun, M. Westerholm, and A. Schnurer 2016. Bacterial Community Composition and FHS Profiles of Low- and high-ammonia Biogas Digesters Reveal Novel Syntrophic Acetate-Oxidising Bacteria. Biotechnol. Biofuels, 9, 48.

Nasr, F. A., and B. Mikhaeil. 2014. Treatment of Domestic Wastewater Using Modified Septictank. Desalination and Water Treatment, 1 - 9.

Sun, L., B. Muller, M. Westerholm, and A. Schnurer. 2014. Syntrophic Acetate Oxidation in Industrial CSTR Biogas Digester. J. Biotechnol. 171, 39 - 44.

Tian, H., I. A. Fotidis, E. Mancini, L. Treu, A. Mahdy, M. Ballesteros, C. GonzalesFernandez, and I. Angelidaki. 2018. Acclimation to Extremely High Ammonia Levels in Continuous Biomethanation Process and The Associated Microbial Community Dynamics. Bioresour. Technol. 247, 616 - 623 .

Wardhani, P. K. 2017. Mathematical and Experimental Study of Anaerobic Digestion Process and Biogas Generation from Fruit and Vegetable Waste. Dissertation. Graduate School of Environmental and Life Science, Okayama University.

Yasar, A., N. Ahmad, H. Latif, and A. A. A. Khan. 2007. Pathogen re-growth in UASB effluent disinfected by UV, O3, $\mathrm{H} 2 \mathrm{O} 2$, and advanced oxidation processes. Ozone: Science and Engineering. 29(6), 485-492.

Yazid, F. R., dan G. Samudro. 2012. Pengaruh Variasi Konsentrasi Dan Debit Pada Pengolahan Air Artifisial (Campuran Grey Water Dan Black Water) Menggunakan Reaktor Uasb. Jurnal Presipitasi. 9(1), 1-1.

Zamalloa, C., J.B.A. Arends, N. Boon, and W. Verstraete. 2013. Performance of a Labscale Bio-electrochemical Assisted Spetic Tank For The Anaerobic Treatment of Black Water. New Biotechnology. 30(5), $573-580$. 